\title{
György Kalmár
}

\section{She-Who-Must-Be-Obeyed}

\author{
Rider Haggard's Victorian romance \\ about She, the veil, and the subject of mâladie
}

"Come," said Ayesha, after we had gazed and gazed, I know
not for how long, "and I will show you the stony flower of
Loveliness and Wonder's very crown, if yet it stands to mock
time with its beauty and fill the heart of man with longing for
that which is behind the veil..."
(Rider Haggard)

This function of speech [...] is no less than the function of indicating the place of the subject in the search for the true.

(Jacques Lacan)

Truth is a woman!

(Friedrich Nietzsche)

In his "L'instance de la lettre dans l'inconscient," Lacan writes about the insistence of a signifying chain in the unconscious that reproduces itself and which is that of dead desire. ${ }^{1}$ In his analysis we can see the subject as the slave of language, caught and defined in this very insistence of the signifier. ${ }^{2} \mathrm{My}$ central concern here - the

\footnotetext{
${ }^{1}$ Jacques Lacan. Écrits. A Selection. Trans. Alan Sheridan. New York and London: Norton, 1977. (Probably this is why the word "instance" in the French title was translated as "insistence" in the version published in David Lodge's Modern Criticism and Theory, while simply given as "agency" in the above quoted English edition of Lacan's Écrits.)

2 "[...] the subject, too, if he can appear to be the slave of language is all the more so of a discourse in the universal moment in which his place is already inscribed at birth..." (Jacques Lacan. Écrits, 148).
} 
insistence of the figure of the veiled woman as a metaphor of truth - can be well described in Lacan's terms. This metaphor, a piece of signifying chain, keeps coming back through the history of literature and philosophy, ${ }^{3}$ eternally repeating itself and with itself the whole structure of the subject, the other, the quest for truth, and the place of jouissance, a dynamic structure driven by the dead desire of the subject inscribed in this very metaphor. The text in which I am going to keep spying on the workings of this image, Rider Haggard's She, is a fine example of this eternal return: an exemplary case on levels of both the signified and the signifier, as well as in its history of reading. As in all similar cases, the narrative may give us as much insight into theory as vice versa, offering a kind of surplus of theory (plus-de-théorie), which comes from the pleasure of the dialogue of different languages, and which is at one and the same time the productive driving force and the incurable sickness, the jouissance and the nuisance of interpretation.

What follows, therefore, is not a reading of a novel in a classical sense. Haggard's text is a con-text in which this little piece of a signifying chain, this metaphor (truth is a veiled woman) may be seen at work. My interest is that of gender studies and cultural studies: how is this patriarchal, phallogocentric imagery set up? Which are the mechanisms of the signifier that create this mythology - our reality - called Western metaphysics?

Feminism, Lacanian psychoanalysis, and deconstruction share an interest in the critical analysis and re-writing of this phallocentric imagery. They join forces here, communicate and debate on the basis of and a propos this text. What results from this 'round table' of critical, post-structuralist theories will not be a unified, well-built and well-dressed-up reading of She. But in a sense this whole feminist, deconstructive - struggle is against such an easy-to-consume understanding of woman, of the one to be known, of every other (tout autre). ${ }^{4}$ Thus, this text, just like the theoretical ones quoted in it, will be both a study into and a struggle against this homo-logic of the culture we inherited. While examining the workings of the metaphor in focus and the text, it will offer a series of metaphors (coming chiefly from theory) that may provide different understandings of truth, woman, the other, the subject of the quest, and, of course, She.

\footnotetext{
${ }^{3}$ For more about the insistence of this metaphor in Plato, Chaucer and others see my essay "A nõi test igazsága: A nõi test mint az igazság metaforája a patriarchális diskurzusban.” Vulgo 1-2 (2000).

${ }^{4}$ In his recent book, Donner la mort (Paris: Galilée, 1999), Jacques Derrida focuses precisely on this problem: the non-murderous understanding of the other as wholly other (tout autre).
} 
THE ETERNAL ROMANCE

The mythical status of She is indisputable.

(C. S. Lewis, Of This and Other Worlds)

Rider Haggard's She has never been out of print since its first publication in 1887. Through the dozens and dozens of editions, serialisations, radio, TV and cinema versions it has inspired a whole series of generations, leaving its mark on - what Jung would call - our collective imagination. As we shall see, the images of the novel seem to be capable of cross-examining some of the most prestigious theories of the subject and textuality that we have in what is generally called post-structuralism.

Of course, like in all such cases, the question of the chicken and the egg - that is, the question of which was first - can rightly be raised: has the novel become so popular because it expresses something strong, basic and influential of our 'collective unconscious,' or is it rather the text that shaped so much our imagination that we cannot but conceptualise and imagine entities of our psychic and cultural life according to its pictures? In other words, has the novel's symbolic structure expressed something already in us, something 'deeply human,' or has it created a 'psycho-symbolic' structure corresponding to its own symbolic one that for some reason or other 'worked out well?' So well, actually, that we still find it hard to get rid of it, or imagine things in other ways.

No doubt, just as in the case of the chicken and the egg, the answer is impossible. What we have knowledge about, what we may know about, is a state (of mind, of imagination, of affairs) into which She is already inscribed. We are always already in this discourse, in the insistence of this metaphor. To tell who was the 'real' subject of enunciation - whether She enunciated 'us' or we did her is not possible. What we experience is the feeling that She has always already been written into 'us,' She is in us, She is a part of us. As if we had been living this romance ever since we learned what it is to desire, as if we had always been living this story. As if She were about us, and our lives were about Her. And this is one of the cases when this 'us' does not necessarily only refer to male subjects, since the matrix of sexual relations that we face in the text affects the life and identity of women as much as that of men. 
So when we read She, we read our own history, our own process of 'subjectivisation.' Our interpretation has to face a sort of epistemological undecidability: we can never tell in which moments we are caught in the hold of this metaphor (and therefore in the phallogocentric tradition), and when we are re-writing it in new directions. This ambiguity is well represented (doubled) in the case of the signifier She. Haggard's romance and its main female character bear the same name, She, both written with a capital $S$ and in italics. The book, an object of our everyday life, and the figure created by its fictional world cannot be distinguished on the level of the signifier. The two ontological orders, the things that the text may do with its readers and the things that the character may do with the other characters, are often difficult to keep separated. My 'intention' is to keep these ambiguities alive, open, and to find the ways in which a critical interpretation - that is by definition aims to be as free of the inherited phallogocentric imagery as possible - can reinterpret this metaphor of the veiled woman precisely by sustaining the ambiguities that threatens to collapse the critical distance necessary for (the illusion of?) such an interpretation.

\section{THE STORY}

One (undoubtedly gloomy and mysterious) English night L. H. Holly, a fellowto-be of a college in Cambridge (the narrator) is visited by his only friend, Vincey, who announces to him that he is going to die and would like to make Holly his heir. He should raise his only son (aged five) and take care of the family heritage, the most interesting part of which is a large box, which becomes the object of mystery, an uncanny thing entering Holly's life. The box should be opened on the twenty-fifth birthday of his son, Leo.

Holly accepts the offer. Vincey leaves, and by the next morning is found dead. Holly raises Leo, and on the twenty-fifth birthday they open the box. It contains another, older box, which contains another (etc.). What they find in the middle of this row of boxes is a potsherd with ancient writings on it, and several other texts, on the basis of which a most mysterious story is revealed to us. The story on the potsherd is written by Amenartas, a princess of Egypt. She and her husband, Kallikrates, flee from Egypt. In the middle of Africa they meet a strange nation the Queen of which falls in love with Kallikrates. She (She is also called Ayesha, and She-who-must-be-obeyed) takes 
them to a mysterious place where she enters some strange phenomenon that she calls the pillar of life and emerges sublimely beautiful. She asks Kallikrates to 'slay' his wife and be her husband, and when covering his eyes and holding on to his wife he resists, she kills him in her anger. The writing of Amenartas is to ask her son (and all her descendants) to take revenge on their father, find and kill the mysterious queen, who is said to be living forever, protected from the natural causes of death. In the rest of the papers we can read the story of the family - or, more precisely, the story of the sons of the family (which fact accidentally gives the impression that from then on the family had only male members, history really being his story) - from the time of the Egyptian empire up to the twentieth century, the story of the quest that no member could complete so far. The task of Leo is of course to accomplish this age-old task of revenge, to go back to the depths of Africa and find the murderer of his ancestor.

Holly (who decides to accompany his adopted son), their servant, Job, and Leo set out on the journey, and after several adventures arrive at the strange nation (where Leo falls in love with a beautiful girl, Ustane), and then at the very court of She-who-must-be-obeyed. It turns out that the story was true, and she really has extraordinary powers, just as she has extraordinary beauty and wisdom. She is a woman no mortal man can resist. In Leo She recognises the reincarnation of Kallikrates, the lover she has been waiting for all these centuries. She kills Ustane and wants to make Leo immortal too, so that they can rule the world together. Of course Leo cannot resist her charms, revenge (for the founding - first - father or Ustane) is out of the question. She takes them to the 'pillar of life,' where she gained her supernatural beauty and immortality, but when she steps into it again so as to show Leo that it is not harmful, the fire undoes the work it has done more than two thousand years ago, and she becomes old, like a mummy, small and monkey-like in a few minutes, then dies. In her last words she asks Leo to wait and search for her, and promises to come back, to be born again for him, to fulfil their love.

Job dies at this shocking sight and the two adventurers return to England, absolutely shattered, only to leave again for central Asia, to find peace of mind (and maybe She) there. 
THE WRITING OF THE OTHER WOMAN

It is with the appearance of language

[that] the dimension of truth emerges.

(Lacan, Écrits)

As one may see, this mysterious and romantic story is started by a piece of writing on an ancient potsherd. It is an uncanny object in the middle of the series of boxes, surrounded by the other, later writings. It is at the same time the characters' (and the reader's) object of desire, object of curiosity, and the little piece of the real in the diegetic reality of the text (in the Lacanian sense) that organises around itself the chains of signification. But in this case the real is not made meaningful (symbolic) through the enunciation of the Father, but through a piece of female writing. It is at the same time written by a woman, and about a woman. In this story the feminine takes all the structurally important positions around the male readers: subject and object of enunciation, writer and topic, murderer and the one in mourning, the one taking away and the one giving life. It is her discourse, her writing that defines the world of the male characters, a world in which these above positions lose their clear lines of distinction, ends meet, the one to be killed may become the one to be loved, the one who writes may be the same as the one who is written about. The characters move in a feminine world. The feminine text that they find in the middle of the boxes may correspond to the 'eternal feminine" being they find in the middle of Africa.

Something is planted into the male readers by this writing that they can never get rid of. They think that they were attracted by the sublime beauty of She, of the materialised ultimate object of desire, but eventually one can clearly perceive that they were already enchanted and entrapped at the moment of reading about her. This piece of feminine writing calls the story to life, just as it

\footnotetext{
"In the interpretation of She, expressions like "eternal feminine" or "écriture féminine" become trapped in aphoristic double binds: literally She-who-must-be-obeyed is an eternal feminine being, just like the writing of Amenartas is a feminine piece of text. Yet, the connection of these expressions with the historical/ critical terms, that is, with their figurative meanings (which have become basic ones in feminist criticism) is quite shaky. The relation of the figure of She to the patriarchal fantasy of the 'eternal feminine' and that of Amenartas's writing to the feminist concept of écriture féminine - at least at this point - seem to be coded in undecidability. The figural/ cultural/ critical meanings of these terms can be both affirmative and deconstructive of the literal meanings established on basis of the text. For more on this problem see the end of this part.
} 
calls the 'souls' of the characters to life. Without this story there would be no novel (no romance), and there would be no character.

Holly and Leo were dead before the story-of-the-woman-about-the-woman awakened desire in them. Desire is opened in them like a question is opened. They want to find the answer to the mystery just as they want to find She. Question and answer, desire and fulfilment, writer and reader, text and interpretation, subject and object of desire, signifier and signified, a void and its filling: this is the set of terms, the matrix or topography that seems to structure the production of meaning at this point. In a peculiar way the text seems to follow a proper Lacanian logic: desire and a symbolic order (of questions, doubts, opinions and possible answers) are generated by the same thing (Thing), at the same moment. It is desire that calls this order to life and it is a symbolic structure that defines the workings of this desire. Together they create the text, a text told by a man in the middle of all these mechanisms, by a subject created by this desire and this order.

What the female text at the topographical centre (and diegetic beginning) of the novel does to these characters, the way it envelopes them in a symbolic structure (in a story) is nothing but placing a piece of fantasy in the middle of their hearts, a kind of demon (daimon) that defines a telos, which is the union of the subject of desire with its object, the subject of questions with its answer, the subject of (the lack of) knowledge with its truth. This fantasy (a phantasm ${ }^{6}$ ) of union at the hypothetical end of their lives becomes the structuring centre of their stories. They are pierced by this writing, and it is this wound that constitutes them as subjects (characters), just like it is this wound that makes them 'proper' men. Their (pre-symbolic) wholeness is broken by this text that cuts a whole right in their middle and writes the fantasy of the other woman there. It is a gesture that castrates and initiates them as men at the same time. Makes them sick, ill, and gives them a hope of healing. In this sense being male (mâle) and being sick (malade) are one and the same thing. The sickness is that of the lack (manque), the same lack that makes them desiring, questioning and questing subjects, emasculating and 'masculating' them at the same time, that is, defining the par excellence condition of the subject in the Lacanian sense. The story of these male

\footnotetext{
6 "[...] fantasm [...] is the form on which depends the subject's desire" (Jacques Lacan. The Ethics of Psychoanalysis. 1959-1960. The Seminar of Jacques Lacan, Book VII. Ed. Jacques Alain Miller. Translated with notes by Dennis Porter. New York and London: Norton, 1992, p. 99).
} 
subjects will always be a story of illness (mâladie), of a sickness called desire, of a sickness called the subject.

The object of union, the medicine (that caused the illness in the first place, like a 'true' pharmakon), She, is elevated to the position of the Thing (das Ding), the ultimate object of desire. The reason for finding her - revenge or love, stabbing or making love to - becomes secondary and undecidable, just like the distinctions between the female subjects of writer and character, subject and object of enunciation. She is jouissance, She is absolute, She is at the beginning and at the end, relating to her must be love and hate, admiration and fear. She is the (hypothetical) place where the subject can heal, where the lack is filled. She is the star and the 'black hole' around which the planets of the characters revolve.

And here one arrives at the point where the writing of the other woman that the male characters read starts working in a 'truly' Derridean way, like a pharmakon, something that causes illness and at the same time is apparently the only way of healing it. On one hand it is the piece of writing that makes the characters the subjects of mâladie, that pierces them, working as a trigger of desire, and, on the other hand, this text offers the only way of easing this lack by giving directions how to reach She, the feminine at the ends of signification, beyond the limits of the masculine world. As we shall see, the act of reading in this scene of the novel is an act of pharmakeia, poisoning, when another substance (the other's substance) is poured into the self, creating an unstable mix, an illness, a strange-tasting cocktail that is the human subject as we know it. Interestingly enough, this place of poisoning and mixture in the novel, the point where ends meet and borders become fluid is also the spot where Lacanian psychoanalysis and the Derridean theory of textuality meet.

As one may read in the Plato's Pharmacy section of Derrida's Dissemination, writing in Plato's Phaedrus (and from then on) is associated with the qualities of the pharmakon: ${ }^{8}$ something that helps remembering, yet being a substitute for remembering makes people forget, something that helps 'living speech' spread and survive, yet kills it as immediate, 'living' sense, and, opening

\footnotetext{
7See the chapters on Das Ding in Lacan's The Ethics of Psychoanalysis (p. 43-70).

${ }^{8}$ It is Socrates who compares the writing brought by Phaidrus to pharmakon (meaning medicine and poison at the same time), a means of seduction in the Platonic dialogue as well. (See: Plato. Phaedrus, Ion, Gorgias, and Symposium, with passages from the Republic and Laws. Trans. with an introduction and Prefatory Notes by Lane Cooper. London, New York, Toronto: Oxford University Press, 1938.)
} 
the supposedly closed system of meaning to numberless new interpretations, corrupts it. One of the effects of this double-edged phenomenon is precisely the above seen blending of opposites. Writing is an in-between (like it is a kind of messenger between the sexes in the novel), one that changes the things it was situated between.

"Writing is not an independent order of signification; it is weakened speech, something not completely dead: a living dead, a reprieved corpse, a deferred life, a semblance of breath." This terrain between life and death, presence and absence, this place playing and moving around in the undecidability of its in-betweenness is precisely the realm of desire in the Lacanian sense. When there is writing, the (fake) presence of what is written announces the presence of the referent, of something that is absent at the time of reading. We read about something (in this case about She), we can see this 'thing,' but we cannot touch it: we feel, we sense but we cannot really reach (the final sense). The Thing of writing is in front of us but worlds away. Writing sets us on a quest for the ultimate signified that we are searching for through the text, but the result is inevitably a failure: the thing can never be ours more than we can be subjects of the piece of writing read. It is this seductive character of the piece of writing on the potsherd that sets off desire in the characters and the story with it.

We have already seen that the piece of female writing and the seduction it accomplishes brings a change into the well-set order of the male characters. In Lacanian terms I have called it piercing and wounding, the creation of a lack that has to be filled along the paths offered by the pharmakon-text that has caused the wound in the first place. Derrida's theory of textuality may serve with another metaphor for this event, giving a slightly different account of the situation. According to him:

In order for these contrary values (good/evil, true/false, essence/appearance, inside/outside, etc.) to be in opposition, each of the terms must be simply external to the other, which means that one of these oppositions (the opposition between inside and outside) must already be accredited as the matrix of all possible opposition. ${ }^{10}$

When the male characters (whose life up to that point is the most orderly) read the piece of female writing (in which the order of opposites is challenged by the

\footnotetext{
' Jacques Derrida. Dissemination. Trans. Barbara Johnson. Chicago: University of Chicago Press, 1981 , p. 143.

${ }^{10}$ Jacques Derrida. Dissemination, p. 103.
} 
similarity or sameness of subject and object of enunciation), when the words of the other (out there) are poured into the ears of the subject (in here) - as poison is, as we have learned from Shakespeare - the chains of ordered signification (an oxymoron, by the way) are upset. One element will not be simply external to its pair, the basic rule of signification (understood in the Saussurean sense as play of differences) is violated. The matrix of signification is changed at a point, one of the elements of its chain of associations is turned inside out. The centre of the novel's male subjects, the heart of these characters, will be inhabited by the female other, by She-who-must-be-obeyed, and this change at one element of the chain will start a whole row of changes, that sweep through the text like a wave, turning inside-out each and every element reached. In a way the novel is nothing but this wave of changes in the chain of signification and the life of the characters. It does not stop until it has reached its end (or got back to its beginning), until everything is turned inside out, until the characters are swept from England to the centre of a volcano in the centre of Africa, until they are swept out of their rational minds, common sense values, misogyny, order and consciousness: till a moment of absolute loss.

All this is started by the little piece of writing of the other woman, coming from another time and another continent. Wounds made by a woman who bears texts and lives in texts, changes caused by a text about a woman and borne by a woman - no wonder that the self-sufficient presence of the male characters is lost forever. For how could a mâladie be cured that is treated by the same pharmakon that caused it?

Our (inevitably metaphysical) way of thinking, which cannot do without defined origins, becomes perplexed here. Where is this so called feminine writing (or pharmakon) coming from? Where is the traumatic real that sets off signification? Where is the impulse coming from that makes the first sentence happen? And what can we do with the detail that this writing is coming from a woman? How can we understand this gendered myth of the birth of the (always already existing) subject of mâladie? Can the thing (Thing) outside the symbolic be gendered? If it cannot, is it possible that what we read through the eyes of the characters is always already a phallocentric reading, a male interpretation of the meaningless moment/eternity of the real before the first moment of time? But if the primordial trauma of a male order can come from a gendered other - like the text of She suggests - how can one (born into this order) know anything about it? 


\section{THE THING IN THE MIDDLE}

As it is noticed by Norman Etherington too, the author of the critical introduction of the 1991 critical edition of She, the most obvious and most often occurring structure of the text is that of the Chinese nest of boxes (xvii). ${ }^{11}$ It is a structure that appears both as a thematic element and as a principle organising the main plot. Undoubtedly, it is an element in case of which one can easily witness the structural turning into the semantic. Among the examples of its occurrences one could list Vincey's already mentioned boxes; the quest of the characters deeper and deeper into the depths of Africa; the courts of the Temple of Truth in the ruined ancient city of Kôr (where She takes the adventurers); Ayesha's caves in the middle of a volcano, surrounded by rocks and then marshes; Ayesha herself, wrapped in her veils; and finally the line of narrators: Haggard (the name of the author) - the fictional 'Editor' (who gets the manuscript from Holly) - and Holly, the narrator (who is inspired by Amenartas's writing and Ayesha).

Of course this structure allows for a series of allegorical interpretations. When the reader or the characters work through the layers constituting it, it can be a journey back in time (like in case of the boxes of Vincey, and the journey into Africa); one from the outside to the inside; from the symbolic to the imaginary (maybe from a point of the real through the symbolic and the imaginary back to a point of the real); from the conscious to the unconscious; from the literal to the figurative; and from the accidental to the essential. No doubt one could organise interpretations of the novel around any of these allegories.

What is (what would be) common in all these interpretations, something that connects them through a characteristic of the very structure that they start from, is that the most important 'thing' can always be found in the middle. The centre of these layers is always on another ontological level, and the thing (Thing) occupying it is always a very special one. The potsherd and its writing constitutes a totally different reality than the late nineteenth century room in Cambridge, Ayesha is of a different order of beings than the other characters, the statue of Truth in the middle of the temple in Kôr makes the characters face the ultimate laws and limits of their existence, and the kingdom of She is moved by entirely

"Ail pareathesised references are to this edition: Rider Haggard. The Annotated She. A Critical Edition of Rider Haggard's Victorian Romance with Introduction and Notes by Norman Etherington. Bloomington and Indianapolis: Indiana Lniversity Press, 1991. 
different laws than that of England. This thing is always that of desire, but not simply the Lacanian objet petit $a$. It is something that is the object and the abject at the same time, a thing the coming (becoming presence) of which must annihilate the subject qua subject. It is the Thing that - becoming the telos - organises the structure around itself, but also that which is capable of destroying the structure, once reached. The best example of this is the character of She.

'She-who-must-be-obeyed' is the perfect name of the object of desire (objetpetit-a) raised to the position of the Thing, the ultimate key to one's jouissance. She lives in an inaccessible place in the depths of Africa ('the dark continent'). One has to travel through seas, deserts, marshes, rooms of her temple, the curtains of her 'chamber,' and her veils to reach her. In a very much emphasised way she is the centre of the world of the novel. She is the fantasy that would fill the lack in the lives of the males on quest, yet it is made clear that no human being can survive her embrace. This double nature, the synchronic existence of opposites that is the characteristic of the Thing, is also shown in her descriptions. Holly depicts her as "terrible but most fascinating" (98), "sublime," "evil," "half-divine" of an "awful loveliness" (105). She is of a human and superhuman order. She is transgression. She is the object and the abject at the same time, one that would bring the fulfilment and the destruction of the subject. She is the woman all men kneel in front of to beg for her love, yet a woman that swears to be the faithful servant of her husband. She is called simultaneously She-who-must-be-obeyed (the most sublime name), and - thanks for the playfulness of the signifier - in the language of the people she rules Hiya, that one can understand as 'Hi ya,' that is, the most colloquial term one may call a woman. She is the most beautiful woman ever seen, but when she steps into the fire the second time she becomes also the most horrible one. It is precisely this meeting of the opposites, this "awful beauty" (a phenomenon strictly analogical to how ends meet in the case of the piece of feminine writing) that constitutes her as the Thing, object and abject, basis and ultimate closure of meaning, sustainer and the only possible destroyer of the symbolic order. She is the object 'beyond the pleasure principle.'

At this place, in this beyond of the order, psychoanalysis and deconstruction can meet for a second time. The thing that is missing, but in the phantasm of characters would make everything complete (in this case She), which Lacan would call the Thing or das Ding, is very close to the Derridean concept of the supplement. The concept of this thing that is missing in the order, but when added to it brings about its de(con)struction seems to be very similar in Lacan, 
Derrida and the novel. She-who-must-be-obeyed is the supplement of the (dead) male order, just as writing is the supplement of speech, and poisoning is that of curing. When She first appears in the novel in the writing of Amenartas she also sets off the dynamism of the supplement the role of which should be to make the dead system run, but can only make it limp. It is of another order so it can never fit perfectly into the given one. That is why there is no perfect order or smoothly going system: something is either healthy, balanced, perfect but dead without movement or change, or sick (malade), off balance, imperfect, limping but living, going somewhere (in the hope of getting cured of its limp that is the possibility of its life). This movement (travelling, significance) is caused and made possible by the limp of the order, which is nothing but the supplement, the part that does not fit, its sickness. This seems to be the same structure and the same dynamism in the cases of the Lacanian subject and the Derridean concept of textuality. The subject is defined by its lack just like speech is defined by its need for its supplement, writing, and the row of objects-to-fill-the-lack is infinite in the same sense as the row of supplements and the supplements of supplements. Derrida's words about the workings of the supplement can be equally true about the Lacanian subject's relation to das Ding, and the role of She in the novel:

the supplement [in our case She] is not, is not a being (on). It is nevertheless not a simple nonbeing (me on), either. Its slidings slip it out of the simple alternative presence/absence. That is the danger. And that is what enables the type always to pass for the original. As soon as the supplementary outside is opened, its structure implies that the supplement itself can be "typed," replaced by its double, and that a supplement to the supplement, a surrogate to the surrogate, is possible and necessary. ${ }^{12}$

The story of the supplements (and their supplements) is the same story as that of a quest for the (lost but never had) Thing that would cease the lack. Our characters are right in the middle of this dynamism, living as long as in need of an other, their supplement, their object of desire. As we shall see in this case they will not only circle around this needed other of the order, but also will fall right into its abyss.

\footnotetext{
12 Jacques Derrida. Dissemination, p. 109.
} 


\section{AYESHA VERSUS LACAN}

There seems to be a strange sort of wrestling going on between Ayesha, the woman mesmerising all men, the figure of the ultimate object of desire, and her male interpreters, first of all, Holly, the narrator. Maybe She is just an object of male fantasy, created by men. Yet, in spite of (or because of?) her ontological undecidability She has a strong grip on these men, and, as we have seen, these men are actually created by her (as men). This may give rise to this odd competition, in which quite important issues are at stake, like understanding, power, the power of understanding (ourselves and the other), being the phallus (that is, the ultimate desired object), and, last but not least, ontological primacy. Amusingly enough, Jacques Lacan, the 'ultimate' interpreter and 'sujet supposé savoir' of issues of desire plays a role very similar to that of Holly, the heart-broken, clumsy-in-love narrator.

First of all, Lacan's description of the location of jouissance utilises the very same images that Holly does in his description of the 'location' of Ayesha. Let us see the truly telling Lacanian passage: "[...] jouissance presents itself as buried at the centre of a field and has the characteristics of inaccessibility, obscurity and opacity; moreover, the field is surrounded by a barrier which makes access to it difficult for the subject to the point of inaccessibility, because jouissance appears not purely and simply as the satisfaction of a need but as the satisfaction of a drive..."13 It is quite obvious that Holly (describing She beyond seas, deserts, marshes etc.) and Lacan are talking about the same land, that of She.

This has at least two important consequences. If we read She from the point of view of Lacan's text, we realise that it is 'différance' written into the symbolic order, civilisation's discontents, the drive and desire generated by its (constituting) lack that leads the novel's characters to She, to her domain. According to Lacan, the main function of the pleasure principle is to keep a distance between the subject and his (her) jouissance, a distance that on the one hand is close enough to maintain a level of energy necessary for the life of the subject, and, on the other hand, big enough not to let the subject be one with jouissance, not to let him (her) be swallowed by it. She is precisely this lacking jouissance of the misogynist civilisation of the male characters, around which it is organised. When they decide to go on a quest, they only follow the pleasure principle in its everlasting circulations around the impossible object. The

\footnotetext{
${ }^{13}$ Jacques Lacan. The Ethics of Psychoanalysis, p. 209.
} 
astonishing thing that happens is that this quest becomes a real one, that is, it takes the characters beyond the pleasure principle, right into the impossible object of jouissance.

The other consequence - that the above similarity of imagery between the Lacan text and that of the novel may lead one to realise - can be gained if one reads the Lacan text from the point of view of She. This would obviously be the realisation that when Lacan aims to create something like a (meta-)theory of desire, he cannot transcend or rise above his object (in the Hegelian sense of Aufbebung), but rather - held by the strength of the signifier - builds his theory from the same material, same imagery, and on the same level as that of the wishful fantasies that he analyses (that he may imagine to 'draw upon'). In other words, his discourse is written by the same forces of desire that have written the poetry of chivalric love, or romances, that is, he is mesmerised and enchanted by the figure of She the same way as Holly is. If Lacan reached the maxim of there being no meta-theory, reading him through She one can realise that there is no real meta-desire (plus-de-désir) either, the characteristics of the theory of desire (and the desire of theory) are the same as that of the desire of She.

Given this, Lacan's (sometimes slightly misogynist) statements about 'woman' gain an ironic double edge of meaning, undercutting his (sometimes truly admirable and annoying) confidence. In the case of sentences, like "You have to admit, that to place in this beyond [of the pleasure principle, in the realm of the Thing] a creature such as woman is a truly incredible idea" ${ }^{14}$ one must smile a little, because Ayesha's example suggests that misogynists such as Holly and Lacan (Holly calls himself that on page 61) may very well be surprised when love strikes, that is, when the structures of desire, which they both seem to have thought themselves superior to in some ways, start working, and their rational knowledge (even of this very structure) does not prevent them from falling prey to it. Here is something that the similarity of the discourse of Lacan and Holly may teach psychoanalysis: theory and meta-theory, desire and the desire to become a master of (that is, above) desire are structured in one and the same way. Misogynists and psychoanalysts fall prey to desire (She) just like anybody else, if not more. Love dupes everyone, and it may dupe the non-dupes (who err) twice, since without them, without the misogynists, woman would never have become Woman, the Thing that rules all.

\footnotetext{
${ }^{14}$ Jacques Lacan. The Ethics of Psychoanalysis, p. 214.
} 
THE FOLLY OF HOLLY

$[\ldots]$ what is important is not that the subject know anything whatsoever.

(Lacan, Écrits)

Indeed, the narrator, Ludwig Horace Holly, is a fine example of the non-dupe who constantly errs. As a narrator, he is of the same kind as Dr Watson of Arthur Conan Doyle, someone with a limited point of view who clings on to his common sense rationalism and empiricism though driven by the mysteries like anyone else. He is small so that we can see the greatness of his other, Holmes or Ayesha, and he is a man of common sense only to be subdued by a higher order. The text of She is full of his sceptical remarks about the seriousness of the quest, but even he has to admit it sometimes that it is as essential to him as it is to Leo.

"Why had I been such a fool as to leave them [his safe rooms in Cambridge]? This is a reflection that has several times recurred to me since, and with ever-increasing force" (40) - writes Holly, and in his lamentations the reader may 'hear' the similar statements of Robinson Crusoe and all other voyagers who become subjects (of novels) only because of their much-lamented decisions that throw them into the abyss of desire. Of course there is no real answer to this 'why.' The subject is a subject only as long as he desires, and starts on a quest to fulfil his desire. As we have seen, being a manly adventurer (mâle) is the same as being sick (malade), lacking something, being wounded. The characters and narrators are always already wounded, subjects of mâladie, that is precisely why they can be characters and narrators. Holly's why is the ultimate signifier of the fate of the subject qua subject, drawn by the whirlpool of his desire.

\section{THE PHILOSOPHER, THE CAVE AND SHE-WHO-MUST-BE-VEILED}

In the narrator one may recognise not only Lacan, but all philosophers and theory-makers on the quest for the sublime Truth of their imagination. The (rational, male) philosopher who started his career in the caves of Plato (being deceived by the shadows on the wall), now - driven by his completely irrational desire - returns to the caves and temples of ancient Kôr, following 
Ayesha. ${ }^{15}$ What he finds there is of course nothing else but the sign of his being deceived again. Ayesha, the sublime beauty, whom he has been chasing through the world turns into a hideous little monkey, and the statue of Truth in the middle of Kôr claims nothing but its own inaccessibility. It may be worth quoting this scene in its entirety, since it undoubtedly constitutes one of the central and most significant scenes of the novel:

"Come," said Ayesha, after we had gazed and gazed, I know not for how long, "and I will show you the stony flower of Loveliness and Wonder's very crown, if yet it stands to mock time with its beauty and fill the heart of man with longing for that which is behind the veil," and, without waiting for an answer, she led us through two more pillared courts into the inner shrine of the old fane.

And there, in the centre of the inmost court, that might have been some fifty yards square, or a little more, we stood face to face with what is perhaps the grandest allegorical work of Art that the genius of her children has ever given to the world. For in the exact centre of the court, placed upon a thick square slab of rock, was a huge round ball of dark stone, some twenty feet in diameter, and standing on the ball was a colossal winged figure of a beauty so entrancing and divine that when I first gazed upon it, illuminated and shadowed as it was by the soft light of the moon, my breath stood still, and for an instant my heart ceased its beating.

The statue was hewn from marble so pure and white that even now, after all those ages, it shone as the moonbeams danced upon it, and its height was, I should say, a trifle over twenty feet. It was a winged figure of a woman of such marvellous loveliness and delicacy of form that the size seemed rather to add to than to detract from its so human and yet more spiritual beauty. She was bending forward and posing herself upon her half-spread wings as though to preserve her balance as she leant. Her arms were outstretched like those of some woman about to embrace one she dearly loved, while her whole attitude gave an impression of the tenderest beseeching. Her perfect and most gracious form was naked, save - and here came the extraordinary thing - the face, which was thinly veiled, so that we could only trace the marking of her features. A gauzy veil was thrown round and about the head, and of its

${ }^{15}$ For a detailed analysis of Plato's allegory of the cave from a similar point of view see: Luce Irigaray. Speculum of the Other Woman. Trans. Gillan C. Gill. Ithaca: Cornell University Press, 1985. Also see: Michelle Boulous Walker. Philosophy and the Maternal Body. London: Routledge, 1998. 
two ends one fell down across her left breast, which was outlined beneath it, and one, now broken, streamed away upon the air behind her.

"Who is she?" I asked, as soon as I could take my eyes off the statue.

"Canst thou not guess, oh Holly?" answered Ayesha. "Where then is thy imagination? It is Truth standing on the World, and calling to its children to try to unveil her face. See what is writ upon the pedestal. Without doubt it is taken from the book of the Scriptures of these men of Kôr," and she led the way to the foot of the statue, where an inscription of the usual Chinese-looking hieroglyphs was so deeply graven as to be still quite legible, at least to Ayesha. According to her translation it ran thus: -

"Is there no man that will draw my veil and look upon my face, for it is very fair? Unto him who draws my veil shall I be, and peace will I give him, and sweet children of knowledge and good works.

And a voice cried. 'Though all those who seek after thee desire thee, behold! Virgin art thou, and virgin art thou go till Time be done. No man is there born of woman who may draw thy veil and live, nor shall be. By Death only can thy veil be drawn, oh Truth!'

And Truth stretched out her arms and wept, because those who sought her might not find her, nor look upon ber face to face."

"Thou seest," said Ayesha, when she had finished translating, "Truth was the Goddess of the people of old Kôr, and to her they built their shrines, and her they sought; knowing that they should never find, still sought they."

"And so," I added sadly, "do men seek to this very hour, but they find not; and, as this Scripture saith, nor shall they; for in Death only is Truth found."

As it can be seen, what is written at the centre of the text is nothing but the inaccessibility of the centre. The winged woman is another metaphor of the ultimate object of desire, just like She. Both are veiled and both live within surroundings showing the structure of the Chinese nest of boxes. Both are figures who finally unveil themselves (Ayesha in her hideous death, Truth in enunciating her own inaccessibility and the structure of impotent longing in which it (she) situates the subject). They are metaphors of each other, just like Amenartas and all the important (beautiful) female characters. They enchant the adventurers, but finally show them what is behind the veil of their projection. These final scenes 
constitute the moments when the imaginary that has become the reality of the characters becomes real. From this perspective, the writing on the statue gains a double meaning. "By Death only can thy veil be drawn" - this could mean on the one hand that one can only experience Truth after death, when s/he ceases to be a subject (constituted precisely by the lack of Truth). But, on the other hand, it can also mean that it is only Death (personified) that is able to unmask Truth, which interpretation would clearly foreshadow the denouement of Ayesha's death, when the hideous monster of the real (that She has always already been) tears off her beautiful imaginary appearance, and shows its real face. This latter reading of the sentence would also serve as a sort of post-structuralist 'conclusion,' according to which Truth (or Woman with a capital w) has to die for us (as something accessible, pleasurable, the presence of sense, meaning, or an intelligible message) before we can see its true (real, meaningless, incoherent, impossible-for-the-subjectto-possess) face.

All this also means, of course, that the other name of She-who-must-be obeyed is She-who-must-be-veiled. It is the veil, the layer of the projections of the imaginary that may turn the real object (of horror) into the sublime imaginary beauty worth following. Those who admire and pursue Truth, Beauty, Woman, etc. have to keep the veil untouched. It is impossible to be a thinker, a philosopher, a non-dupe, unless one dupes himself into the world of the shadows on the wall of the cave. The wisdom of the philosopher is precisely constructed by his folly. As Ayesha says: "Ah, Holly, for all thy wisdom - for thou art wise thou art but a fool running after folly" (128). Of course the word 'for' in "for all thy wisdom" means rather 'because of,' rather than 'in spite of.'

\section{WITHIN HER WORLD}

One of the points of reading where this story of the male subject on his quest after his desire becomes more than a smoothly polished, mirror-like illusion of an allegory (in which everything seems to be so tidy, united and univocal) is when we realise how much the materiality of the text communicates something unexpectedly meaningful from the perspective we have taken. When reading the novel attentively, the reader may notice that it is not only in the line of narration that the female envelops the men on quest (inspired by the writing of a woman they are led to another), but this 'feminisation' of the story's arche and telos is repeated within the very body of the quest. Our adventurers do not simply go 
from the feminine to the feminine (or rather: from the lack of Woman created by the writing of the other woman to the even more radical and even more ambiguous lack of Woman, which itinerary involves all the problems of the symbolic's relation to lack, the imaginary substitute and the place of the real), it is not just by the sameness of beginning and end that they are in the (unequivocal) embrace of the feminine (in this case seemingly dominating in all three domains of the imaginary, the symbolic and the real), but also by the very materiality of the world they live in, which is the same as the materiality of the text, and, in all senses of the word, the materiality of She.

When the adventurers are in Africa, getting closer to where She lives, the text shows more and more examples of what one may call the imagery of the female nude. The river that takes the men to She (her metonymy) is already sexualised: "Presently the moon went down, and left us floating on the waters, now only heaving like some troubled woman's breast..." (41). The house of Shewho-must-be-obeyed is of course a volcano with an enormous (!) crater. This mountain, with its "grandeur," "solitude," "majesty" (85), together with its openness to the sky becomes a perfect metonymy of She, the phallic but desiring woman who inhabits it. Its top not only reaches but seems to "kiss the sky" (85). (No wonder that the first remark of the narrator when seeing it is "It is wonderful... But how do we enter?" [85, my italics].) When She leads the men to the depth of the volcano (the double of the first in many senses) where the pillar of life is, they enter "the very womb of the Earth, wherein she doth conceive the life that ye see..." (189). Since this central cave is not only called the womb of the Earth, but that of the volcano too (199), the two become synecdoches of each other, both feminine and enveloping.

This characteristic of the text is so strong that even the central phenomenon that the adventurers find in the last (and central) of the caves, the pillar of life, despite its phallic name, seems feminine in its nature:

We stood in the third cavern, some fifty feet in length by perhaps as great a height, and thirty wide. It was carpeted with fine white sand, and its walls had been worn smooth by the action of I know not what. The cavern was not dark like the others, it was filled with a soft glow of rosecoloured light, more beautiful to look on than anything that can be conceived. But at first we saw no flashes, and heard no more of the thunderous sound. Presently, however, as we stood in amaze, gazing at the marvellous sight, and wondering whence the rosy radiance flowed, a dread and beautiful thing happened. Across the far end of the cavern, 
with a grinding and crashing noise - a noise so dreadful and aweinspiring that we all trembled, and Job actually sank to his knees - there flamed out an awful cloud or pillar of fire, like a rainbow, many coloured, and like the lightning bright. For a space, perhaps forty seconds, it flamed and roared thus, turning slowly round and round, and then by degrees the terrible noise ceased, and with the fire it passed away - I know not where - leaving behind it the same rosy glow that we had first seen.

"Draw near, draw near!" cried Ayesha, with a voice of thrilling exultation. "Behold the very Fountain and Heart of Life as it beats in the bosom of the great world. Behold the substance from which all things draw their energy, the Bright Spirit of the Globe, without which it cannot live..."

This part clearly indicates a feminine principle of life working in the narrative's universe. The world, its materiality and its substance are all feminine. It is also clear that the 'pillar of life,' the symbol of the substance of life has the same structural position in the text's topography as Ayesha, or the statue of Truth. When we find the pillar in the third, final cave, we meet the same structure of the Chinese nest of boxes that we had to face at most of the important parts of the novel. This also indicates that these things occupying the central position are mutual images (or figures) of each other. This is only confirmed by the similarity in the use of adjectives, since Ayesha, Truth and the pillar of life are all described as beautiful and beyond the beautiful at the same time which results in adjectives like "dreadful," "beautiful," "awe-inspiring," "marvellous" and "awful" next to each other. This means that the sublime Woman, Truth, and the Substance of Life are all one and the same thing, das Ding, the piece of the real that keeps coming back to the same place in different shapes of the imagery. To a place - one has to add - that is by definition empty at the heart of the (mâle/malade) subject of the signifier.

Ayesha's characterisation of the pillar of life also serves as an appropriate description of the work of desire in psychoanalytic theory. Her words about the central thing (Thing) that is "the substance from which all things draw their energy" would make Lacan happy, since according to him the desire of this central (lacking, always already lost) object moves all subjects, and all other objects ("all things") gain importance (even existence) for the subject only as long 
as they serve as metaphors and metonymies of it, as long as $s /$ he wishes and hopes to re-find the lost (original) object in them.

It may need to be added that it is not only the narrator, Holly, who is obsessed with the female body, who creates this female world. The sublime body of She, just like the statue of Truth or the pillar of life, are 'out there' in the diegetic reality of the novel. Ayesha - as the above quoted piece clearly shows speaks the words of the same imagery.

This implies that the whole text (together with the fantasy of its male characters) is strongly sexualised. One could say that it exists only as long as it is sexualised, only as sexualised, as if this was the material from which it was biiit. As if the whole world the adventurers enter were a woman, as if She the character were a synecdoche of She the text, and the body of the novel were analogically built to that of the woman at its centre.

The male subjects of the novel were always already the subjects of She, subjects of this peculiar mâladie, subjected to a fantasy constitutive of what they perceive as reality. They were always already parts of a great plot, puppets in a great show, written by desire. The whole 'show,' the whole world they inhabit (and believe to be real) was called to life by desire. Without She-who-must-be-obeyed there would be no quest, no hero, no material reality, no space to go on quest, no time to live, no Africa, no $19^{\text {th }}$ century, no change, no movement, no character, no plot, nothing.

But can a character (like Holly, Leo, or any of us) ever face this fact? Can any of us ever notice that our story is written by an external force, that it follows patterns plotted by someone else? May we ever realise that we, subjects of a certain cultural/linguistic/discursive order can live with the subjectivity that we consider as our own only since we are subjected to certain metaphors? And finally: can we ever find out where these metaphors are coming from, that is, is it possible to find the plotter behind the invisible plot called reality?

And do we get a different answer once we are taken beyond the pleasure principle?

\section{THE COLONIAL OTHER}

The morning after surviving the terrible storm the adventurers see the first sunrise in Africa. The face that the "other continent" shows them at the dawn of their stay is doubtless of an allegorical nature: 
At length the heralds and forerunners of the royal sun had done their work, and, searching out the shadows, had caused them to flee away. Up he came in glory from his ocean-bed, and flooded the earth with warmth and light. I sat there in the boat listening to the gentle lapping of the water and watched him rise, till presently the slight drift of the boat brought the odd-shaped rock, or peak, at the end of the promontory which we had weathered with so much peril, between me and the majestic sight, and blotted it from my view. I still continued, however, to stare at the rock, absently enough, till presently it became edged with the fire of the growing light behind it, and then I started, as well I might, for I perceived that the top of the peak, which was about eighty feet high by one hundred and fifty thick at its base, was shaped like a negro's head and face, whereon was stamped a most fiendish and terrifying expression. There was no doubt about it; there were the thick lips, the fat cheeks, and the squat nose standing out with startling clearness against the flaming background. There, too, was the round skull washed into shape perhaps by thousands of years of wind and weather, and, to complete the resemblance, there was a scrubby growth of weeds or lichen upon it, which against the sun looked for all the world like the wool on a colossal negro's head. It certainly was very odd; so odd that now I believe that it is not a mere freak of nature but a gigantic monument fashioned, like the well-known Egyptian Sphinx, by a forgotten people out of a pile of rock that lent itself for their design, perhaps as an emblem of warning and defiance to any enemies who approached the harbour.

The first characteristic in this description that may occur to one is the strong imagery of light and darkness that creates a universe of clear-cut binaries. Of course light and darkness form a hierarchical binary, in which light stands for God's grace, while darkness stands for the inferior powers of evil. When the negro's head blots the light from the characters and overshadows them, it becomes evident that they have arrived to an alien, 'godforsaken' land, that of darkness and evil. Their whole existence seems to be overshadowed by this image of the fearsome other.

From the point of view taken before in this essay it may be meaningful to realise that it is the "drift of the boat," that is the river - which the night before was "heaving like some troubled woman's breast..." (41), that is, a clearly feminine 
entity, a metaphor of She - that takes the men under this shadow, away from the majestic "he" of the light.

The connotations of evil are only confirmed when we see this dark face against the "fire of the growing light behind it." Nevertheless, (maybe for the sake of less attentive readers) Job notes on the next page that "I think that the Old Genelman [sic] must have been sitting for his portrait on them rocks" (43), obviously referring to Satan.

These circumstances tend to bring together the different images of the other of the educated, white, Anglo-Saxon, male, Protestant subject, connecting African blacks, woman, and the devil, that is, the others of colonialism, gender and theology. If we consider that the hair of the 'negro' is referred to as "wool," bringing in an image of animality, we may say that the picture is complete.

It is only the last ironic detail of this description - from the point of view of colonialism and the construction of the colonial other - that all these fearsome elements and fiendish characteristics, together, of course, with the commonplace features of a black man's features, are only there "to complete the resemblance" with the real, living blacks. In other words, the description, while taking its detours in the above listed several domains of otherness, preserves the rhetoric of having a real referent in the blacks of Africa.

Undoubtedly, this first view of the other continent implies that what the adventurers are going to encounter there is something absolutely alien, radically other. Indeed, the reader may encounter strange people with strange customs, but - as it often is the case in this genre - all these things seem artificial, like necessary but strikingly unreal painted backgrounds behind the 'real' action of the text. It is not that much the promise content in the quoted passage that is going to be continued in the series of adventures, but rather its way of signification, its mode of constructing the self and its others. The black ("bastard") people of the Amahagger, the 'primitives,' only serve their white queen; and the high civilisation on the ruins of which they live was that of white people. The stranger the customs of the Amahagger are, the more their descriptions smell with the inbreeding, claustrophobia and self-centeredness of the imagination of the European self.

However, the best examples of the function of the colonial other are offered by some obviously unmeditated points of the narration. When we read a part about the ruins of the ancient city Kôr that have not been seen by anyone for 
thousands of years the narrator is forced to explain in a footnote why the Amahagger, who inhabit the land, do not visit or destroy it:

\begin{abstract}
Billali [a tribe leader of the Amahagger] told me that the Amahagger believe that the site of the city is haunted, and could not be persuaded to enter it upon any consideration. Indeed, I could see that he himself did not at all like doing so, and was only consoled by the reflection that he was under the protection of She. It struck Leo and myself as very curious that a people which has no objection to living amongst the dead, with whom their familiarity has perhaps bred contempt, and even using their bodies for purposes of fuel, should be terrified at approaching the habitations that these very departed had occupied when alive. After all, it is only a savage inconsistency.
\end{abstract}

(172-173, italics mine)

What we may see in this passage, which is an explanation in a footnote added to the main text, is that inconsistencies of the narrative are explained by "savage inconsistency." In other words, the problems of the narrative are solved by a projection. The 'savage' will be the place where all knots on the logic of (the white man's) narration can be solved, made straight. Or, to use another metaphor, the 'savage' constitute a nameless space, or a faceless material, a kind of joker in the deck of cards of the narrator, with which all problematic spaces can be filled out, into which anything can be projected. In this sense the alien, the 'other people,' serve as a kind of helper, phantasmic support of the narrative that is able to maintain its unity and consistency. The symbolic structure of the (colonial) narrative needs this consistent support of the phantasmic other of the 'inconsistent savage' to maintain its own integrity.

In the novel, in spite of the promises of the 'negro's head,' in the depths of the other it is always the same, the self, the true self that is found (ruins of a white 'high' civilisation, a beautiful white queen), the phantasmic metaphors and metonymies of the Thing that should be at the core of the self. All the others slaves, aboriginals and white servants - are only to support this tale of the (castrated) I finding (and losing without possessing) its missing part, its phantasmic wholeness in another land. But without them, without the 'digression' through darkness, 'odd' people and their "savage inconsistencies" the narrative could not exist, but would collapse without a moment's existence into solipsism, into the black hole of a short circuit. 
THE PLACE OF THE REAL

If Rider Haggard's She is extraordinary amongst the hundreds of similar works of the age it is that because of the twist at the end that probably hardly any other text accomplishes.

In She the imaginary becomes the reality of the characters, they can encounter the ultimate object of male desire. But this probably would not make She too special. What makes it truly fascinating from the psychoanalytic point of view is that this object of fantasy at the place of das Ding is de-veiled, when after two and a half millenniums of deception She shows her real face. Of course I am talking about the scene in the cave when She steps into the fire for the second time in her life.

As it has been shown above, the ontologically superior place in the text is always the place in the middle, the last of the Chinese nest of boxes. The cave where Ayesha leads her admirers is the last - and therefore most important - of these. One could say that it is the place of the real, where the imaginary beauties are demystified, de-veiled, where the imaginary becomes real.

The similarity between this scene and the one with which the history of philosophy started, the one in Plato's Republic, is truly remarkable. As Irigaray has shown it in her much-quoted analysis, in this scene at the beginning of philosophy the only real thing is the materiality/maternality of the cave that the men sitting in it never seem to notice since their imagination is constantly occupied by the images and shadows projected to its wall. It was then that She first went into the fire, and that these men started to look for her in the works and wonders of this fire instead of trying to understand the real of the situation. It was this two and a half thousands of years that wrote the history of philosophy with the hands of the deluded men who never cared (or dared) to look at the cave, but chased her sublime images. But after all those years She comes back to the cave with her men and steps into the fire for the second time. Now they can see what made her sublime, what caused their delusion. And they can also see the whole process (of 'sublime-ation') undoing itself, getting rid of the veil, of the sublime appearance, and showing her real face, the beyond (or obverse, or price) of male fantasy. A sight that makes them unconscious for some time (falling out from the structure of the subject), kills Job, and makes Leo's hair turn grey...

One could say that the cave was the only real thing from the very beginning, which is also the place of the real, where things show thei: real face, where stories start and end. After all those years it turns out that the 'reality' of 
the light has been constructed by desire and the phantasm of She. This 'reality' was born in this womb-like cave, and now dies at this place too. It is the real of the mother's womb, the real of the beginning and the end, the ultimate place where the delusions created by lack, the fantasy filling this lack, and the Thing's symbolic substitutes disappear. When She turns into a terribly old, horrible, monkey-like creature the history of philosophy, the history of the subject of mâladie reaches its logical end.

\section{AFTER THE FALL}

The place of the real is where the pillar of life meets the human world, where it comes again and again to start and finish stories. When it comes to undo the sublimation that caused the existence of She a story ends, the characters fall out of consciousness for a time. She-who-must-be-obeyed is dead, the ultimate object of desire is lost. But after a time the adventurers come to their senses, come back into a subject form that can speak and write (Holly's narrative is written after the events). In other words, a new story has begun.

One may rightly ask the question: what has changed through the reveiling of the object? And this is undoubtedly one of the central questions here.

The answer of Lacanian psychoanalysis would probably be that one can never tell. What we read is an account written after the fall, and it is hard to know whether the order before was any different. One could also argue that the object that has been lost has never been truly present. If it is lost it means that it has always already been lost, or, at most, it had existence only as something in the act and in the moment of just being lost. And - like in the case of the murdered primordial father in the psychoanalytic 'myth' of Freud - its death has only strengthened its hold on us.

In this sense Rider Haggard's She is a story of genesis, a story that tells us of the loss of the object (that has never been present/ presence) at the beginning of the world that we know. A story about the (eternal, ontological) loss that defines the condition of the subject. From this point of view, the insistence of the text's central metaphor - that of the veiled woman - is nothing but another effect (and constitutive of the dead desire of the subject that I have mentioned at the beginning apropos of Lacan. After reading the story of She and the subjects of maladie the metaphor of truth as a veiled woman seems to be the metaphor of the netonyme structure of the subject "eternally stretching forth towards the desire 
for something else." 16 This is the condition of "being caught in the rails [...] of metonymy," 17 the metonymic sliding of gap-filling fantasies (figures) at the place of the Thing, which is the same sliding of the signifier that produces the history of literature and philosophy above the meaningless face of the real.

In the novel this 'real face of the real' is quickly repressed (the characters go on another quest to find the reincarnation of the lost She) and replaced by a fantasy: "In forms that are historically and socially specific, the $a$ elements, the imaginary elements of the fantasm come to overlay the subject, to delude it at the very point of das Ding." With this the story obviously gets back to its point of origin, to the point that is probably the beginning of all stories (like that of the story stretching from Plato to Derrida), when a fantasy stands in place of the lacking Thing and makes the characters leave on a quest to find it. All these events seem to follow each other like inevitable phases of the building and re-building of symbolic universes based on the insistence of certain signifying chains and the productive lack of the central object, the object that was lost without ever being present, and will never be found again.

${ }^{16}$ Jacques Lacan. Écrits, p. 167.

${ }_{17}^{17}$ Jacques Lacan. Écrits, p. 167.

${ }^{18}$ Jacques Lacan. The Ethics of Psychoanalysis, p. 99. 